Creative Commons User License: CC BY-NC-ND

Abstracted by: EBSCOhost, Electronic Journals Service (EJS),

Google Scholar, Journal Seek, Scientific Commons,

Food and Agricultural Organization (FAO), CABI and Scopus
Journal of Agricultural Extension

Vol. 23 (4) October, 2019

ISSN(e): 24086851; ISSN(Print); 1119944X

http://journal.aesonnigeria.org

http://www.ajol.info/index.php/iae

Email: editorinchief@aesonnigeria.org

\title{
Influence of Entrepreneurship Education on Career Aspiration of Agriculture Undergraduates in Rivers State
}

https://dx.doi.org/10.4314/jae.v23i4.13

\section{Ifeanyi-obi, Chinwoke Clara}

Department of Agricultural Economics and Extension, University of Port Harcourt, Rivers State Nigeria

Email: clara.ifeanyi-obi@uniport.edu.ng; Phone: +2348033397055

\section{Ewurum, Thanksgiving}

Department of Agricultural Economics and Extension, University of Port Harcourt, Rivers State Nigeria

Email: ewurum.thanksgiving@yahoo.com; Phone:+23481679291152

\section{Abstract}

The study assessed the influence of entrepreneurship education on career aspiration of agriculture undergraduates in Rivers State. Two stage sampling procedure was used to select 94 final year undergraduates for the study. Data were collected from the respondents on their demographic characteristics, choice of career, perception of career in agriculture, factors that influence their career aspiration, effectiveness of the entrepreneurship course taken and its influence on their career aspiration using structured questionnaire and analysed with mean, frequency count, percentages, binary logit and ordinary least square regression analysis. Findings showed that minimal take off fund (88\%), desire to develop entrepreneurship skills (87\%), low level of mechanization (81\%), intrinsic desire for the career (74\%), less difficulty to access agric. fund (68\%), social status of those already in agric. career $(67 \%)$ and family and environmental factors (60\%) were major factors influencing students' career aspirations. The major influences of entrepreneurship education on students' career aspiration include developing creativity in students ( $\bar{x}=3.4)$, increasing students' self-confidence $(\bar{x}=3.5)$, aiding financial management ( $\bar{x}=3.5$ ), becoming entrepreneurial oriented ( $\bar{x}=3.6)$ and increasing students' ambition of being self-employed ( $\bar{x}=3.5)$. There was a strong relationship between the agriculture undergraduate's choice of course at entry, family involvement in home gardening, family residence, mode of financial support and their choice of career. Also, student's perception of career in agriculture was found to be influenced by their age, course applied for at entry, family involvement in home gardening and career choice after entrepreneurship education. Entrepreneurship courses should be made more practical for better understanding and increased impact. Government should give soft agricultural loans to young agricultural graduate to encourage them take up a career in agricultural.

Keywords: Entrepreneurship, career aspiration, career choice, influence, factors 
Creative Commons User License: CC BY-NC-ND

Abstracted by: EBSCOhost, Electronic Journals Service (EJS), Google Scholar, Journal Seek, Scientific Commons,

Food and Agricultural Organization (FAO), CABI and Scopus
Journal of Agricultural Extension

Vol. 23 (4) October, 2019

ISSN(e): 24086851; ISSN(Print); 1119944X

http://journal.aesonnigeria.org

http://www.ajol.info/index.php/iae

Email: editorinchief@aesonnigeria.org

\section{Introduction}

It has been generally observed that unemployment of graduates of Nigerian tertiary institutions has become a major national problem. Thousands of university graduates join the labour market in search of gainful employment yearly. It is also observed that people enrol in educational programmes in higher institutions (such as university, polytechnic, colleges, institutions, etc) with the hope of acquiring knowledge and a view of being gainfully employed at the end of the programme. This hope has not been actualized for so many graduates. According to Owusu-Ansha and Poku (2012), the challenge is not only to tackle the large number of unemployed graduates, but also of absorbing the new entrants into the labour market. It is generally believed that many graduates were unemployed because the training they received was not adequate to equip them with desirable skills and competencies required for job creation and self-employment (Ekundayo \& Babatunde, 2014; Akpochafo \& Alika, 2018)). It was on this note that entrepreneurship education was developed into schools' curriculum. Entrepreneurs are people who have the ability to see and evaluate business opportunities; to gather the necessary resources to the advantage of them; and to initiate appropriate action to ensure success (Mainoma \& Aruwa, 2012; Baba, 2013; Ojeifo, 2013). Umunadi (2014) stated that entrepreneurs are people who constantly discover new markets, try to figure out how to supply those markets sufficiently and make profit.

Entrepreneurs are therefore innovative minds that have the ability to see and evaluate business opportunities. Effective education is expected to stimulate the entrepreneurial spirit in individuals, initiating the use of their innovative intelligence to evolve solutions to problems. Education is the process of receiving or giving systematic instruction. It facilitates learning or the acquisition of knowledge, skills, values, beliefs, and habits. Entrepreneurship education is the education that prepares people to be responsible and enterprising individual. It helps people develop the skills, knowledge, and attitudes necessary to achieve the goals they set out for themselves. According to Akinwumi (2012), entrepreneurship is the act of identifying, initiating, organizing and bringing a vision to life, be it a new product, service, process, organizational strategy, promotional strategy or a niche market. Effective entrepreneurship education is expected to help agricultural students develop positive mindset towards their career in agriculture as well as nurture their entrepreneurial minds. Many graduates of agriculture do not aspire to build a career in agriculture not just because of the non-mechanized nature of agriculture in the country but mainly due to wrong orientation and lack of entrepreneurial skill and initiative needed to succeed in the agricultural sector, hence the drift of agriculture graduates to other sectors of the economy (Olatunji, Opurum \& Ifeanyi-obi, 2012).

Existing curricula in most of our tertiary institutions were developed by the colonial masters (Oyeleke \& Akinyeye, 2013). According to them, these curricula were narrowly and stereotypically lopsided considering only the needs of the colonial masters, consequently, many of the curricula in Nigeria education system, particularly at the tertiary level, are not geared towards effective national sustainable development. Many graduates of such programmes are not easily employed or selfemployed and in most cases have to wait for many years after graduation to secure 
Creative Commons User License: CC BY-NC-ND

Abstracted by: EBSCOhost, Electronic Journals Service (EJS), Google Scholar, Journal Seek, Scientific Commons,

Food and Agricultural Organization (FAO), CABI and Scopus
Journal of Agricultural Extension

Vol. 23 (4) October, 2019

ISSN(e): 24086851; ISSN(Print); 1119944X

http://journal.aesonnigeria.org

http://www.ajol.info/index.php/iae

Email: editorinchief@aesonnigeria.org

jobs. Hence the rate of unemployment among university and polytechnic graduates in Nigeria was as high as $71.4 \%$ (Yoloye, 2008). The rationale for the inclusion of entrepreneurship curricula in universities is to produce enterprising Graduates who are 'able to create and/or recognize opportunities, which have the will and initiative to seize these opportunities' in any context (Salihu, 2016) Entrepreneurship education is therefore expected to focus on the development of skills or attributes that enable the realization of opportunities; provide students with the knowledge, skills and motivation to encourage entrepreneurial success in a variety of settings. The question now is, how effective are the entrepreneurship courses offered in the Faculties of Agriculture in Rivers State? Do they meet the objective of entrepreneurship education? If not, how could they be improved to be more effective. It is against this background that this study assessed the influence of entrepreneurship education on career aspiration of agriculture undergraduate.

\section{Objective of the Study}

The broad objective of this study was to examine the influence of entrepreneurship education on the career aspiration of agriculture undergraduates in Rivers State.

The specific objectives were to:

1. identify the choice of career of agriculture undergraduate before and after taking the entrepreneurship course;

2. assess agricultural undergraduate perception of career in agriculture;

3. identify the factors that influence students' career aspiration in agriculture;

4. determine the perceived effectiveness of the entrepreneurship course taken by agriculture undergraduates; and

5. assess the influence of entrepreneurship education on career aspiration of agriculture undergraduates.

\section{Hypothesis of the Study}

The under-stated hypotheses were tested in the study:

$H_{0}$ : There is no significant relationship between the agriculture undergraduates' demographic characteristics and their choice of career.

\section{Methodology}

This study was undertaken in Rivers State. The State is situated in the extreme south of Nigeria and is one of Nigeria's Niger Delta State. The State is located on Latitude $4^{0} 45^{\prime} \mathrm{N}$ and longitude 6050' $\mathrm{E}$. The State has an area of $11,077 \mathrm{Km}^{2}$ and a population of 5,198716 (Annual abstract of statistics, 2011). Rivers State share boundaries with Imo State, Abia State and Anambra State in the North, Akwalbom State in the East, Bayelsa State and Delta State in the West, and the Atlantic Ocean in the South. The State was formed on the $27^{\text {th }}$ of May, 1967. The people of the State are referred to as the Riverines.

The study was carried out in universities having the faculties of agriculture in the State namely, Rivers State University, University of Port Harcourt and Ignatius Ajuru University of Education, Rumuolumeni. The population for the study included all final year agriculture undergraduates who have studied entrepreneurship courses in Universities across Rivers State. Two-stage sampling procedure was used for the 
Creative Commons User License: CC BY-NC-ND

Abstracted by: EBSCOhost, Electronic Journals Service (EJS), Google Scholar, Journal Seek, Scientific Commons,

Food and Agricultural Organization (FAO), CABI and Scopus
Journal of Agricultural Extension

Vol. 23 (4) October, 2019

ISSN(e): 24086851; ISSN(Print); 1119944X

http://journal.aesonnigeria.org

http://www.ajol.info/index.php/jae

Email: editorinchief@aesonnigeria.org

study The first comprised of random selection of two out of the three universities that have faculty of agriculture namely University of Port Harcourt and Rivers State University. The second stage comprised the proportionate random selection of $30 \%$ (from each department) of the final year students in the faculty of agriculture from the two selected universities. Data were collected using structured questionnaires and analysed using, percentages, mean scores, binary logit regression analysis and ordinary least square regression analysis.

\section{Model Specification}

1. $\mathrm{H}_{0}$ : There is no significant relationship between agriculture students' demographic characteristics and their choice of career.

This was tested using binary logit regression analysis, the model is stated below:

The dependent variable for this study is dichotomous therefore Binomial logistic regression model was used, 0 when an undergraduate choice of career is nonagricultural and 1 when it is agricultural. Predictor variables are a set of sociodemographic indicators of the agriculture undergraduate. They include both dichotomous and continuous variables. Let $\mathrm{Pj}$ denote the probability that the $\mathrm{j}$-th undergraduate is choosing an agricultural career. We assume that $\mathrm{Pj}$ is a Bernoulli variable and its distribution depends on the vector of predictors $X$, so that:

$P_{j}(X)=\underline{e^{\alpha+\beta X}}$

$1+e^{\alpha+\beta X}$

The logit function to be estimated is then written as:

$\ln \left\{\mathrm{P}_{\mathrm{j}} /\left(1-\mathrm{P}_{\mathrm{j}}\right)\right\}=\alpha+\sum, \beta_{i} X_{i j}$

The logit variable $\ln \{\mathrm{Pj} /(1-\mathrm{Pj})\}$ is the natural log of the odds in favour of the agriculture undergraduate choosing agricultural career.

The binary logit model to be estimated is specified as follows:

$C_{i j}=\beta_{0}+\beta_{1 i n c}+\beta_{2}$ pol $+\beta_{3 \text { cons }}+\beta_{4 d e c}+\beta_{5 \text { sav }}+\beta_{6 \text { asset }}+\beta_{7 f a m s u p}+\beta_{80}$ grg $+u$

To estimate the above model, binary logit technique was used. The dependent variable for the logit model takes the binary form $\left(p=C_{i j}\right)$, which has probability equals to 1 if the agriculture undergraduate chooses agricultural career and 0 otherwise. The coefficient estimates of $\beta$ gives the change in the log-odds (logarithm of relative probabilities) of the outcome-here $=1-$, for a one-unit increase in the independent variable, holding all other independent variables constant. Logit regressions are estimated using Maximum Likelihood (ML) rather than OLS. ML calculates coefficient estimates that maximize the likelihood of the sample data set being observed.

$\mathrm{C}_{\mathrm{ij}},=$ Dummy $=1$ if the agriculture undergraduate chooses agricultural career and 0 otherwise.

$\mathrm{X}_{1}=\operatorname{Sex}$ (Dummy: Male $=1$, Female $=2$

$\mathrm{X}_{2}=$ Age (years)

$X_{3}=$ Course applied for at entry (Agricultural $=1$, otherwise $=2$ ) 
Creative Commons User License: CC BY-NC-ND

Abstracted by: EBSCOhost, Electronic Journals Service (EJS), Google Scholar, Journal Seek, Scientific Commons,

Food and Agricultural Organization (FAO), CABI and Scopus
Journal of Agricultural Extension

Vol. 23 (4) October, 2019

ISSN(e): 24086851; ISSN(Print); 1119944X

http://journal.aesonnigeria.org

http://www.ajol.info/index.php/iae

Email: editorinchief@aesonnigeria.org

$\mathrm{X}_{4}=$ Family involve in home gardening (Yes $=1$, No =2)

$\mathrm{X}_{5}=$ Family residence (Rural area $=1$, Urban $=2$ )

$X_{6}=$ Mode of Financial support (self-trained $=1$, otherwise $=2$ )

$\mathrm{X}_{7}=$ Choice of career before the entrepreneurship course (Agriculture $=1$, nonagriculture $=2$ )

$\mathrm{X}_{8}=$ Choice of career after the entrepreneurship course (Agriculture $=1$, nonagriculture $=2$ )

$\mathrm{u}=$ stochastic error term.

2. $\mathrm{H}_{0}$ : There is no significant relation between the agriculture undergraduate demographic characteristics and their perception of career in agriculture

This was tested using Ordinary least square multiple regression analysis, the model is implicitly stated below:

$$
Y=f\left(x_{1}, x_{2}, x_{3}, x_{4}, x_{5}, x_{6}, e\right)
$$

Where $Y=$ Pooled index of agriculture undergraduate's perception of career in agriculture, measured with a 4-point-likert type scale of Strongly Agree (4), Agree (3), Disagree (2), and Strongly Disagree (1).

$\mathrm{X}_{1}=\operatorname{Sex}($ Dummy: Male $=1$, Female $=2$

$\mathrm{X}_{2}=$ Age (years)

$X_{3}=$ Course applied for at entry (Agricultural $=1$, non-agriculture $=2$ )

$\mathrm{X}_{4}=$ Family involve in home gardening (Yes $\left.=1, \mathrm{No}=2\right)$

$\mathrm{X}_{5}=$ Family residence (Rural area $=1$, Urban $\left.=2\right)$

$X_{6}=$ Mode of Financial support (self-trained $=1$, otherwise $=2$ )

$\mathrm{X}_{7}=$ Career choice before entrepreneurship course (Agriculture $=1$, Non Agriculture $=2$ )

$\mathrm{X}_{8}=$ Career choice after entrepreneurship course (Agriculture $=1$, Non Agriculture $=$ 2)

$$
\mathrm{E}=\text { Error term }
$$

It is expected a priori that the coefficients of $X_{1} X_{2}, X_{3}, X_{4}, X_{5}, X_{6}, X 7, X 8>0$

Four functional forms of the model namely linear, double log, exponential and semilog were estimated. A lead equation was chosen based on the appropriateness of signs, magnitude of coefficient of multiple determination $\left(R^{2}\right)$, statistical significance of the variables and a priori theoretical expectations. The relationship between the dependent and each of the independent variables was examined using the four functional forms: linear, semi-log, exponential and double- log.

Linear: $\mathrm{Y}_{=} \mathrm{B}_{0}+\mathrm{B}_{1} \mathrm{X}_{1}+\mathrm{B}_{2} \mathrm{X}_{2}+\mathrm{B}_{3} \mathrm{X}_{3}+\mathrm{B}_{4} \mathrm{X}_{4}+\mathrm{B}_{5} \mathrm{X}_{5}+\mathrm{B}_{6} \mathrm{X}_{6}+\mathrm{B}_{7} \mathrm{X}_{7}+\mathrm{B}_{8} \mathrm{X}_{8}+\mathrm{e}$

Semi-Log: $Y_{=} B_{0}+B_{1} \log X_{1}+B_{2} \log X_{2}+B_{3} \log X_{3}+B_{4} \log X_{4}+B_{5} \log X_{5}+$

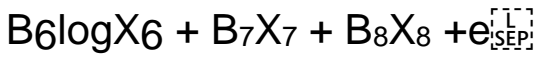

Exponential: $\log \mathrm{Y}_{=} \mathrm{B}_{0}+\mathrm{B}_{1} \mathrm{X}_{1}+\mathrm{B}_{2} \mathrm{X}_{2}+\mathrm{B}_{3} \mathrm{X}_{3}+\mathrm{B}_{4} \mathrm{X}_{4}+\mathrm{B}_{5} \mathrm{X}_{5}+\mathrm{B}_{6} \mathrm{X}_{6}+\mathrm{B}_{7} \mathrm{X}_{7}+\mathrm{B}_{8} \mathrm{X}_{8}$

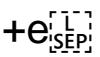


Creative Commons User License: CC BY-NC-ND

Abstracted by: EBSCOhost, Electronic Journals Service (EJS), Google Scholar, Journal Seek, Scientific Commons,

Food and Agricultural Organization (FAO), CABI and Scopus

http://eoi.citefactor.org/10.11226/v23i4
Journal of Agricultural Extension

Vol. 23 (4) October, 2019

ISSN(e): 24086851; ISSN(Print); 1119944X

http://journal.aesonnigeria.org

http://www.ajol.info/index.php/iae

Email: editorinchief@aesonnigeria.org

Double Log: $\log \mathrm{Y}_{=} \mathrm{B}_{0}+\mathrm{B}_{1} \log \mathrm{X}_{1}+\mathrm{B}_{2} \log \mathrm{X}_{2}+\mathrm{B}_{3} \log \mathrm{X}_{3}+\mathrm{B}_{4} \log \mathrm{X}_{4}+\mathrm{B}_{5} \log \mathrm{X}_{5}+\mathrm{B}_{6}$ $\log \mathrm{X}_{6}+\mathrm{B}_{7} \mathrm{X}_{7}+\mathrm{B}_{8} \mathrm{X}_{8}+\mathrm{e}$

\section{Results and Discussion}

\section{Choice of Career of Agriculture Undergraduate Before and After Taking the Entrepreneurship Course}

Table 1 indicates that the choice of career for the majority (68\%) of the agriculture students before taking entrepreneurship course was non-agriculture and agriculture $(71 \%)$ after taking the entrepreneurship course. This is encouraging and an indication that the entrepreneurship course has a positive impact on the student's career choice. Before taking the entrepreneurship course, Livestock (9\%), Crop farming $(7 \%)$ and fish farming $(7 \%)$ were the most desired career choice among the agriculture students while Agriculture product marketing (23\%) and fish farming $(20 \%)$ became the most desired career choice after taking the course.

Table 1: Choice of career in agriculture.

\begin{tabular}{lll}
\hline Choice of Career & & Percentage \\
\hline $\begin{array}{l}\text { Choice of career before taking the } \\
\text { entrepreneurship course }\end{array}$ & Agriculture & 31.9 \\
Specific choice of career before the & Non-Agriculture & 68.1 \\
entrepreneurship course & Livestock farmer & 8.5 \\
& Crop farmer & 7.4 \\
& Fish farmer & 7.4 \\
& Agricultural extension & 3.2 \\
& agent & \\
& Agric product marketer & 5.3 \\
Choice of career after taking the & No career & 68.4 \\
entrepreneurship course & Agriculture & 71.3 \\
& & \\
Specific choice after the & Non-Agriculture & 28.3 \\
entrepreneurship course & Livestock farmer & 14.9 \\
& Crop farmer & 8.5 \\
& Fish farmer & 20.2 \\
& Agricultural extension & 3.2 \\
& agent & \\
& Agric product marketer & 23.4 \\
& No career & 29.8 \\
\hline
\end{tabular}

Source: Field Survey, 2018 
Creative Commons User License: CC BY-NC-ND

Abstracted by: EBSCOhost, Electronic Journals Service (EJS), Google Scholar, Journal Seek, Scientific Commons,

Food and Agricultural Organization (FAO), CABI and Scopus
Journal of Agricultural Extension

Vol. 23 (4) October, 2019

ISSN(e): 24086851; ISSN(Print); 1119944X

http://journal.aesonnigeria.org

http://www.ajol.info/index.php/jae

Email: editorinchief@aesonnigeria.org

\section{Agriculture Undergraduate's Perception of Career in Agriculture}

The result in Table 2 indicates that undergraduates in the Faculty of Agriculture, Universities in Rivers State agree that choosing a career in agriculture would enable them do other businesses $(\bar{x}=3.5)$, stimulate their initiative $(\bar{x}=3.6)$, easily breakthrough and be recognized for their skills $(\bar{x}=3.4)$, offer them opportunities for research $(\bar{x}=3.4)$ and become their own bosses $(\bar{x}=3.6)$. This is in line with a study conducted by Owusu-Ansah, (2004) which highlights that entrepreneurship education causes a stir in students to own a business after school.

\section{Table 2: Agriculture undergraduates' perception of career in agriculture}

\begin{tabular}{|c|c|}
\hline Variable & Mean \\
\hline Agriculture allows me progress in my career speedily & $2.87^{*}$ \\
\hline There is flexibility in the career & $3.1596^{\star}$ \\
\hline The profession allows me enough time & $2.94^{*}$ \\
\hline Career in Agric gives me the opportunity to work as a team & $3.17^{*}$ \\
\hline Agriculture gives me the opportunity to be a thinker & $3.23^{*}$ \\
\hline Agric will allow me practice what I know & $3.22^{*}$ \\
\hline Agric can allow me be my own boss & $3.62^{*}$ \\
\hline I can start my own business with little resource & $3.22^{*}$ \\
\hline Agric has minimal life-threatening risks I can cope with & $3.06^{*}$ \\
\hline Agric makes me stimulates my initiatives & $3.36^{*}$ \\
\hline I can easily breakthrough and be recognized for my skills & $3.42^{*}$ \\
\hline The discipline can allow me do other business & $3.57^{*}$ \\
\hline I look forward to own a farm and employ people & $3.40^{*}$ \\
\hline It is a field that offers me research opportunities & $3.44^{*}$ \\
\hline $\begin{array}{l}\text { It allows me become a researcher and food producer with high social } \\
\text { status }\end{array}$ & $3.44^{*}$ \\
\hline The profession will not stifle my initiatives and creativity & $3.16^{*}$ \\
\hline It is not a sex discriminating profession & $3.19^{*}$ \\
\hline I go not have to depend on gov't for employment & $3.44^{*}$ \\
\hline Agriculture has high prospects & $3.36^{*}$ \\
\hline
\end{tabular}

Source: Field Survey, 2018: * means agree

Factors Influencing Students' Career Aspirations in Agriculture

Table 3 shows that minimal take off fund (88.3\%), low level of mechanization $(81.9 \%)$, desire to develop entrepreneurial skills $(87.2 \%)$, intrinsic desire for agricultural career $(74.5 \%)$, social status of those already involved in agricultural career $(67 \%)$, less risks associated to agricultural careers $(59.6 \%)$, societal perception of agricultural endeavours (60.6\%) and family and environmental factors $(54.3 \%)$ were major factors that influence students' career aspirations in agriculture. Other factors include peer pressure (54.3\%) and attaining social prestige (53.2\%). 
Creative Commons User License: CC BY-NC-ND

Abstracted by: EBSCOhost, Electronic Journals Service (EJS), Google Scholar, Journal Seek, Scientific Commons,

Food and Agricultural Organization (FAO), CABI and Scopus
Journal of Agricultural Extension

Vol. 23 (4) October, 2019

ISSN(e): 24086851; ISSN(Print); 1119944X

http://journal.aesonnigeria.org

http://www.ajol.info/index.php/iae

Email: editorinchief@aesonnigeria.org

It is not surprising to see that low level of mechanization and social status of those already in agricultural sector influences career choice of agriculture undergraduate as many youths see agricultural activities as very tasking and a career of low esteem. This result agrees with Olatunji et al (2012), which identifies perception of job prospect as a factor influencing agriculture undergraduate's eagerness to take up career in agriculture upon graduation.

\section{Table 3: Factors influencing students' career aspirations in agriculture}

\begin{tabular}{ll}
\hline Factors & Percentages \\
\hline Minimal take off fund & 88.3 \\
Less difficulty to access fund for agriculture purposes & 68.1 \\
Social status of those already in agriculture career & 67.0 \\
Low level of mechanization & 81.9 \\
Intrinsic desire for it & 74.5 \\
Desire to develop entrepreneurship skill & 87.2 \\
Less risks associated to it & 59.6 \\
Family and Environmental factors & 54.3 \\
Society perception of career in agriculture & 60.6 \\
Peer pressure & 43.6 \\
Social prestige or status & 44.7
\end{tabular}

Source: Field Survey, 2018.

\section{Agricultural Undergraduates' perception of the effectiveness of the entrepreneurship course}

It was shown in Table 4 that the undergraduates agree that the entrepreneurship course(s) was learnt at an ideal level $(\bar{x}=3.1)$ but could also be taken at a higher or lower level. According to the students, though the level at which the course is taken could be seen as appropriate, they feel it may be more appropriate to take it at a lower level as it will help them have a better disposition to learn other courses. Also taken it at a higher level may impact more on their career choice as they leave the university. The findings also showed that the content of the entrepreneurship course taken is appropriate $(\bar{x}=2.8)$ but lacked some important aspects $(\bar{x}=2.99)$. Furthermore, the agriculture undergraduates were not contended with the teaching methodology $(\bar{x}=2.81)$ and this may be due to the fact that the undergraduates felt the course was not sufficiently practicalized $(\bar{x}=3)$.

From the findings, it is seen that the students are not contented with the practical level of the entrepreneurship course as well as some important aspect which they felt is lacking in the course. This calls for a review of the course outline/content and an upgrade to the practical aspect of the course so as to maximize the impact of the course on the career choice of the agriculture undergraduates. 
Creative Commons User License: CC BY-NC-ND

Abstracted by: EBSCOhost, Electronic Journals Service (EJS), Google Scholar, Journal Seek, Scientific Commons,

Food and Agricultural Organization (FAO), CABI and Scopus
Journal of Agricultural Extension

Vol. 23 (4) October, 2019

ISSN(e): 24086851; ISSN(Print); 1119944X

http://journal.aesonnigeria.org

http://www.ajol.info/index.php/jae

Email: editorinchief@aesonnigeria.org

Table 4: Agricultural undergraduates' perception of the effectiveness of the entrepreneurship course taken

\begin{tabular}{ll}
\hline Variable & Mean \\
\hline The level at which the course was taken was ideal & $3.10^{*}$ \\
The course is better taken at lower & $2.83^{*}$ \\
The course is best taken at a higher level & $2.86^{*}$ \\
The course content is appropriate & $2.84^{*}$ \\
The course content lacks some important aspects of the course & $2.99^{*}$ \\
The methodology of teaching the course is appropriate & $2.73^{*}$ \\
The methodology of teaching the course is not appropriate & $2.81^{*}$ \\
The course is not sufficiently practical base & $3.00^{*}$ \\
The course is sufficiently practical base & 2.49
\end{tabular}

Source: Field Survey, 2018: * means agree

\section{Perception of the Influence of Entrepreneurship Education on Career Aspiration of Agriculture Undergraduates in Rivers State}

The major perceived influence of entrepreneurship education on career aspiration of agriculture undergraduates in Rivers State is presented in Table 5. This includes boosting of ego $(75 \%)$, equipped them with the ability to promote economic growth $(71 \%)$, equipped them with the ability to contribute to poverty alleviation $(68 \%)$, increased their capacity of being job creators $(65 \%)$ and developed their skill for selfemployment $(59 \%)$. The undergraduates through the skill acquired during the entrepreneurship course are more confident to own a livestock farm (73.4\%), fish farm $(64.9 \%)$, crop farm $(69.1 \%)$ or being an extension agent $(59.5 \%)$ with $39.4 \%$ stating that they no longer had the interest of working in a non-agricultural firm. A more immediate impact of entrepreneurship education could be seen in the fact that it could make $87.2 \%$ of the undergraduates more resourceful and $92.5 \%$ more creative. This agrees with a study conducted by Mudashir, Rozilah, and David (2014) which found out that undergraduates began to have value for resources and also be creative with entrepreneurship education. 
Creative Commons User License: CC BY-NC-ND

Abstracted by: EBSCOhost, Electronic Journals Service (EJS),

Google Scholar, Journal Seek, Scientific Commons,

Food and Agricultural Organization (FAO), CABI and Scopus
Journal of Agricultural Extension

Vol. 23 (4) October, 2019

ISSN(e): 24086851; ISSN(Print); 1119944X

http://journal.aesonnigeria.org

http://www.ajol.info/index.php/iae

Email: editorinchief@aesonnigeria.org

Table 5. Perception of the influence of entrepreneurship education on career aspiration of agriculture undergraduates in Rivers State

\begin{tabular}{ll}
\hline Perception & Mean \\
\hline Entrepreneurship education has exposed me to entrepreneurship process & $3.40^{*}$ \\
My knowledge in managing farm has increased through entrepreneurship education & $3.33^{*}$ \\
Entrepreneurship education has increased my ambition of being self-employed & $3.50^{*}$ \\
Through entrepreneurship education my skill for self-employment was developed & $3.38^{*}$ \\
I became more entrepreneur oriented after taking entrepreneurship education & $3.36^{*}$ \\
My self-confidence as a potential agriculture professional developed through & $3.54^{*}$ \\
entrepreneurship education & \\
Entrepreneurship education aids improve my agricultural finance management skills & $3.35^{*}$ \\
I am equipped to contribute to poverty alleviation through entrepreneurship education & $3.32^{*}$ \\
I am equipped to promote economic growth through entrepreneurship education & $3.27^{*}$ \\
Entrepreneurship education helped increase my writing skills on business proposals & $3.41^{*}$ \\
Entrepreneurship education increased my capacity to be a job creator & $3.34^{*}$ \\
I am more confident to own a livestock farm & $3.20^{*}$ \\
I am more confident to own a fish farm & $3.15^{\star}$ \\
I am more confident to own a crop farm & $3.28^{*}$ \\
Entrepreneurship education has made me more confident to be an extension professional & $2.74^{*}$ \\
Entrepreneurship education has increased my capacity on been an agricultural consultant & $3.30^{*}$ \\
After entrepreneurship education, I no longer aspire to work in non-agricultural outfit & 2.31 \\
After Entrepreneurship education, I now realize I can have self-fulfilment working as an & $3.19^{*}$ \\
agricultural professional & \\
Entrepreneurship education has boosted my ego as a potential agricultural professional & $3.22^{*}$ \\
I became a more resourceful agricultural student after Entrepreneurship course & $3.22^{*}$ \\
Entrepreneurship education developed creativity in me & $3.42^{*}$
\end{tabular}

Source: Field survey, 2018: * means agree

\section{Relationship between Agriculture Undergraduates' Demographic Characteristics and Students' Choice of Career.}

Table 6 shows the relationship between the demographic characteristics of the undergraduates and their choice of career. The logistic regression was statistically significant $\left(X^{2}=b 21.380, p \leq .005\right)$. The model explained $52 \%$ of the variation in career choice of the agriculture undergraduates. Course applied for at entry, family involvement in home gardening, family residence, and mode of financial support correlated significantly with the choice of career of agriculture undergraduates. This implies that those who reside in rural areas could have more interest in agriculturerelated courses. Similarly, people whose families are involved in home gardening would be more interested in taking up careers in agriculture. 
Creative Commons User License: CC BY-NC-ND

Abstracted by: EBSCOhost, Electronic Journals Service (EJS),

Google Scholar, Journal Seek, Scientific Commons,

Food and Agricultural Organization (FAO), CABI and Scopus
Journal of Agricultural Extension

Vol. 23 (4) October, 2019

ISSN(e): 24086851; ISSN(Print); 1119944X

http://journal.aesonnigeria.org

http://www.ajol.info/index.php/jae

Email: editorinchief@aesonnigeria.org

Table 6. Relationship between students' choice of career and their demographic characteristics

\begin{tabular}{lll}
\hline Variable & Coefficient & t-ratio \\
\hline Constant & $\mathbf{0 4 0}$ & $\mathbf{0 . 3 2}$ \\
Age & 0.20 & 0.60 \\
Sex & 0.01 & 0.90 \\
Department & 0.05 & 0.29 \\
Course applied for at entry & 1.92 & $5.88^{\star}$ \\
Family involvement in home gardening & 0.74 & $2.77^{*}$ \\
Family residence & 0.72 & $2.12^{*}$ \\
Mode of financial support & 0.66 & $1.99^{*}$ \\
Ethnic group & 0.03 & .96 \\
\hline
\end{tabular}

${ }^{*} \leq 0.05$

\section{Conclusion and Recommendations}

Entrepreneurship education was perceived to influence students' career choice in agriculture. The desire to take up career in agriculture was increased after taking the entrepreneurship course. The entrepreneurship courses should be made more practical and taken at lower level as this would make undergraduates more acquainted to entrepreneurial processes, have a better understanding and also appreciate entrepreneurship education. Government policies that would protect the intellectual properties of undergraduates and young graduates would encourage more undergraduates and young graduates to go into new businesses and invention of innovation. Soft loans should be provided to agricultural undergraduates both by the Government and the University as to encourage them develop their entrepreneurial ideas into businesses. Conditions for awarding the loans should be attainable and favourable to fresh graduates. Orientation for fresh agriculture undergraduates should be taken more seriously as most of them are people who never applied to agriculture or have the desire to do anything in agriculture but were in agriculture as a result of their not being able to secure their choice course. It is very important to give them the right orientation that will integrate them properly into the faculty of agriculture and help them have the right disposition to study agriculture.

\section{References}

Akpochafo, G.O. \& Alika, I.H. (2016). Perceived impact of entrepreneurship education on career development among undergraduates in South-South Universities in Nigeria: Implication for counselling. Journal of education and Learning, 7(3), 102-108.

Anthony U.O., Virginia A.O,, \& Chinwe E.O. (2012). Entrepreneurial Dynamics. First edition: Equity Ventures \& Mega Atlas Projects limited

Baba, G.K. (2013). "The Challenges of Entrepreneurship Development in Nigeria and Way Forward", Journal of Business and Organizational Development, Vol. 5(1) 
Creative Commons User License: CC BY-NC-ND

Abstracted by: EBSCOhost, Electronic Journals Service (EJS), Google Scholar, Journal Seek, Scientific Commons,

Food and Agricultural Organization (FAO), CABI and Scopus
Journal of Agricultural Extension

Vol. 23 (4) October, 2019

ISSN(e): 24086851; ISSN(Print); 1119944X

http://journal.aesonnigeria.org

http://www.ajol.info/index.php/iae

Email: editorinchief@aesonnigeria.org

Chuma O.N, Pearl C.A, Chizoba D.N (2013). Impact of entrepreneurship education on the career aspirations of Nigeria Para-professional Liberians-in-Training. Academic Journal of Interdisciplinary Studies. 2(5)

Ekundayo, B.B. \& Babatunde, E.D. (2014). The Impact of Entrepreneurship Education on Entrepreneurial Intensions among Nigeria Undergraduates. International Journal of Research in Humanities, Arts and Literature. 2(1), 15-26

Emmanuel, E.A, Dazala, I.U. \& Daniel, J.D. (2012). Entrepreneurship Education and Attitude of Undergraduate Students to Self-Employment in Mubi, Adamawa State, Nigeria. Journal of Education and Practice. 3(8), 95-110

Kumara, S.P.A.P. (2012). Undergraduate Intention towards Entrepreneurship: Empirical Evidence from Sri Lanka. Journal of Enterprising Culture 2(1), 105-118.

Madushir, G., Rozilah, A. \& David, M. (2014). Is the Impact of Entrepreurship Education as Remarkable as the Demand? Faculty of Technological Management and Business, Universiti Tun Hussien Onn Malaysia, Parit Raja Batupahat Johor, Preceeding Bbooks of ICETSR, Malaysia Handbook on the emerging trends in scientific research.

Mainoma, M.A and Aruwa, S.A.S. (2012). Entrepreneurship: Principles, Processes\& Development, Felicity Publishing co. Ultd, Kaduna, Nigeria

Nnadozie, C.O., Akonwa, P.C., \& Nnadozie, C.D. (2013). Impact of Entrepreneurship Education on the Career Aspirations of Nigerian Para-professional Librarians-inTraining. Academic Journal of Indisciplinary Studies. 2(5), 149-161.

Ojeifo, S.A. (2013). Entrepreneurship Education in Nigeria. A Panacea for Youth Unemployment. Journal of Education and Practice, Vol. 4(6).

Oyeleke, O. and Akinyeye, C.O (2013). Curriculum Development in Nigeria; Historical Perspectives. Journal of Educational and Social Research, 3(1) 73

Olatunji, S.O, Opurum, L.C and Ifeanyi-obi, C.C. (2012) Factors influencing students' choice of career in agriculture in South South universities in Nigeria. African Journal of Agriculture, Technology and Environment, 1(1): 14-23.

Salihu, A.J., (2016). Effect of Entrepreneurship Education on Graduates Business Start up in North Central Nigeria. European Journal of Business and Management. 8(20), 48-62.

Umunadi, E.K. (2014).Entrepreneurial, Technical and Vocational Skills Required for SelfReliance and Job Creation in Nigeria. British Journal of Education, 2(5) 48-56

Wokocha, K.D. Appah, C., \& Ezeji, V.N. (2012). Wealth Creation in Aspects of Entrepreneurial Potentiation: Cognition to Practice (Ed. Obaji, A.U \& Eigbiremhon, 1) $1^{\text {st }}$ Ed Ominini: Equity Ventures and Mega Atlas Projects. www.quickmba.com>quickmba>entrepreneurship retrieved 18-2-2018 